BMJ Open

Diabetes

Research

\& Care

\title{
Dipeptidyl peptidase- 4 inhibition by Saxagliptin prevents inflammation and renal injury by targeting the Nlrp3/ASC inflammasome
}

\author{
Yochai Birnbaum, ${ }^{1,2}$ Mandeep Bajaj, ${ }^{3}$ Jinqiao Qian, ${ }^{1,4}$ Yumei $Y e^{1}$
}

To cite: Birnbaum Y, Bajaj M, Qian J, et al. Dipeptidyl peptidase-4 inhibition by Saxagliptin prevents inflammation and renal injury by targeting the NIrp3/ASC inflammasome. BMJ Open Diabetes Research and Care 2016;4:e00227.

doi:10.1136/bmjdrc-2016000227

YB and MB contributed equally.

Received 16 March 2016 Revised 21 June 2016 Accepted 27 June 2016

This final article is available for use under the terms of the Creative Commons Attribution Non-Commercial 3.0 Licence; see http://drc.bmj.com

CrossMark

For numbered affiliations see end of article.

Correspondence to Professor Yumei Ye; yumye@utmb.edu

\section{ABSTRACT}

Background: Glucagon-like peptide-1 (GLP-1) receptor activation delays the progression of diabetic nephropathy (DN) in rodents. The NOD-like receptor 3 (NIrp3) inflammasome plays an important role in DN. Dipeptidyl peptidase-4 inhibitors (DPP4I) inhibit the degradation of endogenous GLP-1 and various other active substances. We assessed whether DPP4I attenuates diabetes-induced activation of the inflammasome and progression of DN in mice with type 2 diabetes mellitus (T2DM) and type 1 diabetes mellitus (T1DM).

Methods: BTBR (T2DM), Akita (T1DM) and their matched non-diabetic control (wild-type (WT)) mice received 8-week treatment with Saxagliptin (Saxa) or vehicle.

Results: Kidney weight and kidney/body weight ratio increased in the BTBR and Akita mice compared to their WT mice. Saxa attenuated these changes in the BTBR, but not in the Akita mice and had no effect in the WT mice. Serum blood urea nitrogen and creatinine significantly increased in the BTBR and Akita mice. Saxa attenuated the increase in the BTBR and Akita mice. Saxa improved glycemic control in the BTBR mice, but had no effect on glucose levels in the Akita and WT mice. Serum $C$ reactive protein, tumor necrosis factor $\alpha$ (TNF $\alpha$ ), interleukin (IL)-1 $\beta$, IL -6 and $\mathrm{IL}-18$ were significantly higher in the BTBR and Akita mice than in the WT mice. Saxa attenuated the increase in the BTBR and Akita mice. Kidney and adipose protein levels of apoptosis-associated speck-like protein 1, NLRP3, TNF $\alpha$ and Caspase-1 were higher in the BTBR and Akita mice than in the WT mice. Saxa reduced the levels in both types of diabetic mice.

Conclusions: Saxa attenuated diabetes-induced activation of the inflammasome and progression of DN. As Saxa did not affect glucose levels in the Akita mice, these effects are independent of glucose lowering.

\section{INTRODUCTION}

According to the National Diabetes Statistics Report 2014, in 2012, 29.1 million Americans (9.3\% of the population) had diabetes mellitus (DM). Among Americans $\geq 65$ years of age, $25.9 \%$ (11.8 million people) had DM. In 2013, a total of 1469000 new cases of

\section{Key messages}

- Serum blood urea nitrogen and creatinine significantly increased in the BTBR and Akita mice. Saxa attenuated the increase in the BTBR and Akita mice.

- Serum $C$ reactive protein, tumor necrosis factor $\alpha(\mathrm{TNF} \alpha)$, interleukin (IL)-1 $\beta, \quad \mathrm{IL}-6$ and IL-18 were significantly higher in the BTBR and Akita mice than in the WT mice. Saxa attenuated the increase in the BTBR and Akita mice.

- Kidney and adipose protein levels of apoptosis-associated speck-like protein 1, NLRP3, TNF $\alpha$ and Caspase-1 were higher in the BTBR and Akita mice than in the WT mice. Saxa reduced the levels in both types of diabetic mice.

diagnosed DM among adults (aged 1879 years) were reported in the USA. DM is the leading cause of kidney failure $(44 \%$ of all new cases in 2011). In 2011, a total of 228924 American people of all ages with kidney failure secondary to DM were treated with chronic dialysis or underwent kidney transplant (http://www.cdc.gov/diabetes/ data/index.html). ${ }^{1}$ It is well known that inhibition of the renin-angiotensin system by either ACE inhibitors or angiotensin type 1 receptor blockers delays, but cannot completely prevent, the progression of diabetic nephropathy (DN). ${ }^{2}$ No other established intervention has been reported to prevent and/or ameliorate DN beside the indirect effects of lowering glucose levels. ${ }^{3}$

Glucagon-like peptide-1 (GLP-1) augments glucose-dependent insulin secretion. ${ }^{4}$ GLP-1 receptor is also expressed in endothelial cells and the kidney. ${ }^{5-9}$ GLP-1 has antiinflammatory actions. GLP-1 receptor activation inhibits the expression of vascular cell adhesion molecule-1 and tumor necrosis factor $\alpha(\mathrm{TNF} \alpha)^{10}$ in endothelial cells, and $\mathrm{NF \kappa B}$ and intercellular adhesion molecule-1 (ICAM-1) in the kidney. ${ }^{11}$ Moreover, it was suggested that GLP-1 receptor activation increases 
intracellular cyclic adenosine monophosphate (cAMP) with subsequent activation of protein kinase $\mathrm{A}$ and downstream inactivation of phospho-c-Raf/phosphor-Erk 1/2, which are activated by angiotensin II. ${ }^{12}$ This attenuates angiotensin II-induced upregulation of plasminogen activator inhibitor-1 (PAI-1), CD68 and CXCL2 levels. ${ }^{12}$ Several studies have suggested that GLP-1 receptor activation ameliorates DN in rodents. ${ }^{11}{ }^{13-17}$ However, Mima et $a l^{12}$ suggested that the protective effect of GLP-1 is attenuated by hyperglycemia and free fatty acids, as hyperglycemia and high levels of free fatty acids upregulate protein kinase C $\beta$ that decreases GLP-1 receptor expression and activates the proinflammatory phosphor-c-Raf.

Dipeptidyl peptidase-4 inhibitors (DPP4I) inhibit the degradation of endogenous GLP-1 and, therefore, augment its circulation levels. ${ }^{18}$ However, DPP4Is also prevent the degradation of other non-GLP-1 substrates such as glucose-dependent insulinotropic peptide (GIP), B type natriuretic peptide, substance $\mathrm{P}$, neuropeptide $\mathrm{Y}$, peptide YY, bradykinin and stromal-derived factor $1 \alpha$ (SDF-1 $\alpha)$ and, thus, could have effects that differ from that of pure GLP-1 receptor activation. ${ }^{18}$ The effects of DPP4I on the progression of DN have been less described. It was reported that DPP4I-induced natriuresis in non-diabetic mice was independent of the GLP-1 receptors. Moreover, in mice with type $2 \mathrm{DM}$ (T2DM, db/db), DPP4I (alogliptin), in contrast to the GLP-1 receptor agonist, Exendin-4, failed to inhibit renal fluid and sodium reabsorption. ${ }^{19} \mathrm{On}$ the other hand, Kodera et $a t^{20}$ reported that DPP4I with PKF275-055 attenuated inflammation, NFkB activation and delayed the progression of $\mathrm{DN}$ in rats with type $1 \mathrm{DM}$ (T1DM, streptozotocin-induced).

The NOD-like receptor 3 (Nlrp3) inflammasome is an interleukin (IL)-1 $\beta$ family cytokine-activating protein complex. The inflammasome plays an important role in the inflammation associated with $\mathrm{T} 2 \mathrm{DM}^{21-24}$ and various forms of renal injury. ${ }^{25-27}$ Nlrp3 interaction with apoptosis-associated speck-like protein (ASC) leads to activation of caspase-1, with subsequent increase in the production of proinflammatory cytokines. ${ }^{23} 25{ }^{26}$ It is reported that glyburide (sulfonylurea) prevents activation of inflammasome and delays lipopolysaccharide-induced lethality in mice. ${ }^{28}$ The Nlrp3 inflammasome is involved in $\mathrm{DN}$ in the rat and could be inhibited with allopurinol. ${ }^{29}{ }^{30}$ An in vitro study suggested that DPP4I represses the Nlrp3 inflammasome and IL-1 $\beta$ expression in macrophages. ${ }^{31}$ However, the effects of GLP-1 and or DPP4I treatment on the activation of the Nlrp3 inflammasome in the diabetic kidney has not been reported. We investigated the effects of Saxagliptin (Saxa) on the development of DN and Nlrp3 inflammasome activation using a mouse model of T1DM and T2DM.

\section{METHODS}

Treatment

Male BTBR ob/ob mice $\left\{\right.$ BTBR.V(B6)-Lep $\left.{ }^{o b} / \mathrm{Wisc} J\right\}$, male C57BL/6 mice (wild-type (WT) control for the BTBR), male AKITA mice $\left\{\mathrm{C} 57 \mathrm{BL} / 6 \mathrm{NJcl}-\mathrm{Ins} 2^{\text {Akita }}\right\}$ and male C57BL/6NJcl mice (WT control for the Akita) were purchased from Jackson Laboratory. ${ }^{32} 33$ At an age of 8 weeks, mice received (1) C57BL/6+vehicle; (2) BTBR +vehicle; (3) BTBR+Saxa; (4) C57BL/6NJcl+vehicle; (5) C57BL/6NJcl+Saxa; (6) AKITA+vehicle and (7) AKITA + Saxa. As the genetic background of the C57BL/6 and $\mathrm{C} 57 \mathrm{BL} / 6 \mathrm{NJcl}$ is considered close enough, we omitted the group of C57BL/6+Saxa to look for the effects of Saxa in non-diabetic animals. Saxa $(10 \mathrm{mg} / \mathrm{kg} /$ day $)$ was mixed with the normal chow $(276.7 \mathrm{mg} / \mathrm{kg}$ of chow) and was administered for 8 weeks. After completion of treatment, body weight was measured and fasting glucose was determined using a glucometer (One Touch, Wako Diagnostics, Richmond, Virginia, USA).

All animals received humane care in compliance with the Guide for the Care and Use of Laboratory Animals, published by the National Institutes of Health (NIH Publication number 85-23, Revised 1996). The protocol was approved by the Institutional Animal Care and Use Committee of the University of Texas Medical Branch.

\section{Glucose tolerance test}

Intraperitoneal glucose tolerance test (IGTT) was carried out after 8-week treatment. Mice had fasted for $4 \mathrm{~h}$ prior to IGTT. Glucose $(1 \mathrm{~g} / \mathrm{kg}$ of body weight $)$ was injected intraperitoneally. Blood samples were collected from the tail vein before $(0 \mathrm{~min})$ and $30,60,90$ and 120 min after the glucose administration. Blood glucose levels were determined using glucometer.

\section{Enzyme-linked immunosorbent assays}

After anesthetizing the animals with ketamine $(20 \mathrm{mg} / \mathrm{kg})$ and xylazine $(4 \mathrm{mg} / \mathrm{kg})$, blood was collected from the left ventricle. Plasma was collected using EDTA as an anticoagulant. Samples were centrifuged for $15 \mathrm{~min}$ at $1000 \times \mathrm{g}$ at $2-8^{\circ} \mathrm{C}$ within $30 \mathrm{~min}$ of collection. $\mathrm{C}$ reactive protein (CRP), IL-1 $\beta$, IL-18, IL-6 and TNF $\alpha$ levels in serum were determined by ELISA (R\&D Systems, Minneapolis, Minnesota, USA).

\section{Kidney function}

The weights of kidneys (KW) and the ratio KW/body weight were determined. Blood urea nitrogen (BUN) and creatinine were estimated as markers of renal dysfunction.

\section{Renal morphology assessment}

Samples were fixed in 4\% paraformaldehyde and embedded in paraffin wax. Five-micrometer thick sections were stained for routine histopathological diagnosis with H\&E. Periodic acid of Schiff (PAS) staining was performed to evaluate the interstitium of the kidney. High-quality digital images suitable for quantitative analysis were captured from PAS-stained section using light microscope (Olympus DP71) at a magnification of $\times 400$. The glomerular tuft area was measured (at least 50 samples) using Image $J$ software. The mean glomerular area was 
obtained. Then PAS-positive material in each glomerulus was quantified and expressed as a percentage of the glomerular tuft area (fractional mesangial area). ${ }^{34} 35$

\section{Western blot analysis}

Renal cortex and adipocyte levels of TNF $\alpha$, NLRP3, ASC1 and Caspase-1 were evaluated by western blot. Samples were homogenized in lysis buffer (in $\mathrm{mM}$ ): 25 Tris- $\mathrm{HCl}$ $(\mathrm{pH}$ 7.4), 0.5 EDTA, 0.5 EGTA (ethylene glycol-bis ( $\beta$-aminoethyl ether)-N,N, $\mathrm{N}^{\prime}, \mathrm{N}^{\prime}$-tetraacetic acid), 1 phenylmethylsulfonyl fluoride, 1 dithiothreitol, $25 \mathrm{NaF}, 1$ $\mathrm{Na}_{3} \mathrm{VO}_{4}, 1 \%$ Triton $\mathrm{X}-100,2 \%$ SDS and $1 \%$ protease inhibitor cocktail. The lysate was centrifuged at $10000 \times \mathrm{g}$ for $15 \mathrm{~min}$ at $4^{\circ} \mathrm{C}$ and supernatants were collected. Protein concentration was determined by the Bradford method. Protein $(50 \mu \mathrm{g})$ was fractionated by SDS-PAGE (4-20\% polyacrylamide gels) and transferred to polyvinylidene difluoride (PVDF) membranes (Millipore, Bedford, Massachusetts, USA).

After blocking, membranes were incubated with primary antibodies anti-TNF $\alpha$, anti-ASC1, anti-caspase-1 (Santa Cruz Biotechnology, USA), anti-NLRP3 (R\&D System, USA) or anti- $\beta$-actin (Sigma-Aldrich, USA) overnight at $4^{\circ} \mathrm{C}$. The membranes were then washed and incubated with secondary membrane horseradish peroxidase (HRP)-conjugated antibodies for $1 \mathrm{~h}$ at room temperature. Bound antibodies were detected using the chemiluminescent substrate (NEN Life Science Products, Boston, Massachusetts, USA). The protein signals were quantified with an image-scanning densitometer, and the strength of each protein signal was normalized to the corresponding $\beta$-actin signal. Data are expressed as per cent relative the expression in the control group (WT+vehicle).

\section{Reverse transcription polymerase chain reaction}

Total RNA from isolated mouse renal and adipose tissue was extracted using TRIzol reagent (Invitrogen, Carlsbad, California, USA) according to the protocol per manufacturer's instruction. Two micrograms of total RNA from each sample was reverse transcribed into cDNA and equal amounts of the reverse transcriptional products were subjected to PCR amplification. The evaluation of mRNA expression of TNFo, NLRP3, ASC, Caspase-1, IL1 $\beta$, IL6 and IL18 was performed by using the primers reported in table 1. The Ct (threshold cycle) is defined as the number of cycles required for the fluorescence signal to exceed the detection threshold. Expression of the gene relative to the glyceraldehyde 3-phosphate dehydrogenase (GAPDH) was calculated as the difference between the threshold values of these two genes $\left(2^{-\Delta \mathrm{Ct}}\right)$. Melting curve analysis was performed during real-time PCR to analyze and verify the specificity of the reaction. The values are given as the means $\pm \mathrm{SE}$ of four independent experiments. Each sample was analyzed in triplicate and normalized by GAPDH.

\section{RESULTS}

Body weight (figure 1A) of the BTBR mice was significantly higher than the WT mice $(\mathrm{p}<0.001)$. Body weight in the BTBR+Saxa group was significantly higher than in the WT group, but lower than in the BTBR group $(p<0.001)$. Body weight was comparable between the WT and Akita mice. Saxa had no effect on body weight in the WT and Akita mice.

Kidney weight (figure 1B) and the kidney weight/body weight ratio (figure $1 \mathrm{C}$ ) were significantly higher in the BTBR than in the WT group ( $p<0.001$ for both). Kidney weight and the kidney/body weight ratio were significantly lower in the BTBR+Saxa group compared to the BTBR group ( $p<0.001$ for both). Kidney weight and the kidney/ body weight ratio were significantly higher in the Akita than in the WT mice $(p<0.001$ for both). Saxa had no effect on these parameters in the WT and the Akita mice.

Serum BUN (figure 1D) and creatinine (figure 1E) were significantly higher in the BTBR mice than in the WT mice $(p<0.001)$. Saxa attenuated the increase in the BTBR mice $(p<0.001$ vs BTBR; $p<0.009$ vs $W T)$. Serum BUN and creatinine were significantly higher in the Akita mice than in the WT mice $(\mathrm{p}<0.001$ for both). Saxa had no effect on BUN and creatinine in the WT mice; however, it attenuated the increase in BUN and creatinine in the Akita mice $(\mathrm{p}<0.001$ for both vs Akita).

Fasting serum glucose was significantly higher in the BTBR $(339.0 \pm 10.0 \mathrm{mg} / \mathrm{dL})$ than in the WT mice $(107.7$ $\pm 2.9 \mathrm{mg} / \mathrm{dL} ; \quad \mathrm{p}<0.001)$. Saxa significantly reduced glucose levels in the BTBR mice $(163.8 \pm 5.9 \mathrm{mg} / \mathrm{dL}$; $\mathrm{p}<0.001$ vs $B$ TBR and $\mathrm{WT}$ ) ( $\mathrm{n}=6$ per group). Serum fasting glucose was significantly higher in the Akita mice $(404.0 \pm 10.0 \mathrm{mg} / \mathrm{dL})$ than the WT mice $(122.4 \pm 3.8 \mathrm{mg} /$ $\mathrm{dL} ; \mathrm{p}<0.001)$. In contrast to the effect in the BTBR

Table 1 Primer sequences for real-time RT-PCR

\begin{tabular}{lll}
\hline Symbol & Forward primer & Reverse primer \\
\hline Caspase-1 & GAGCTGATGTTGACCTCAGAG & CTGTCAGAAGTCTTGTGCTCTG \\
TNF $\alpha$ & GACCCTCACACTCAGATCATCTTCT & TGCTACGACGTGGGCTACG \\
IL-1 $\beta$ & CCCTGCAGCTGGAGAGTGTGG & TGTGCTCTGCTTGAGAGGTGCT \\
IL-6 & TAGTCCTTCCTACCCCAATTTCC & TTGGTCCTTAGCCACTCCTTC \\
IL-18 & AAGAACAAGATCATTTCCTTTGAGGA & GGAACACGTTTCTGAAAGAATATGA \\
GAPDH & CTCTGTATGGCAATGTGCTGAC & GAACAAGTTCTTGCAGGTCAG \\
ASC, apoptosis-associated speck-like protein; IL, interleukin; TNF $\alpha$, tumor necrosis factor $\alpha$. & CTGGAAGATGGTGATGGGTT
\end{tabular}



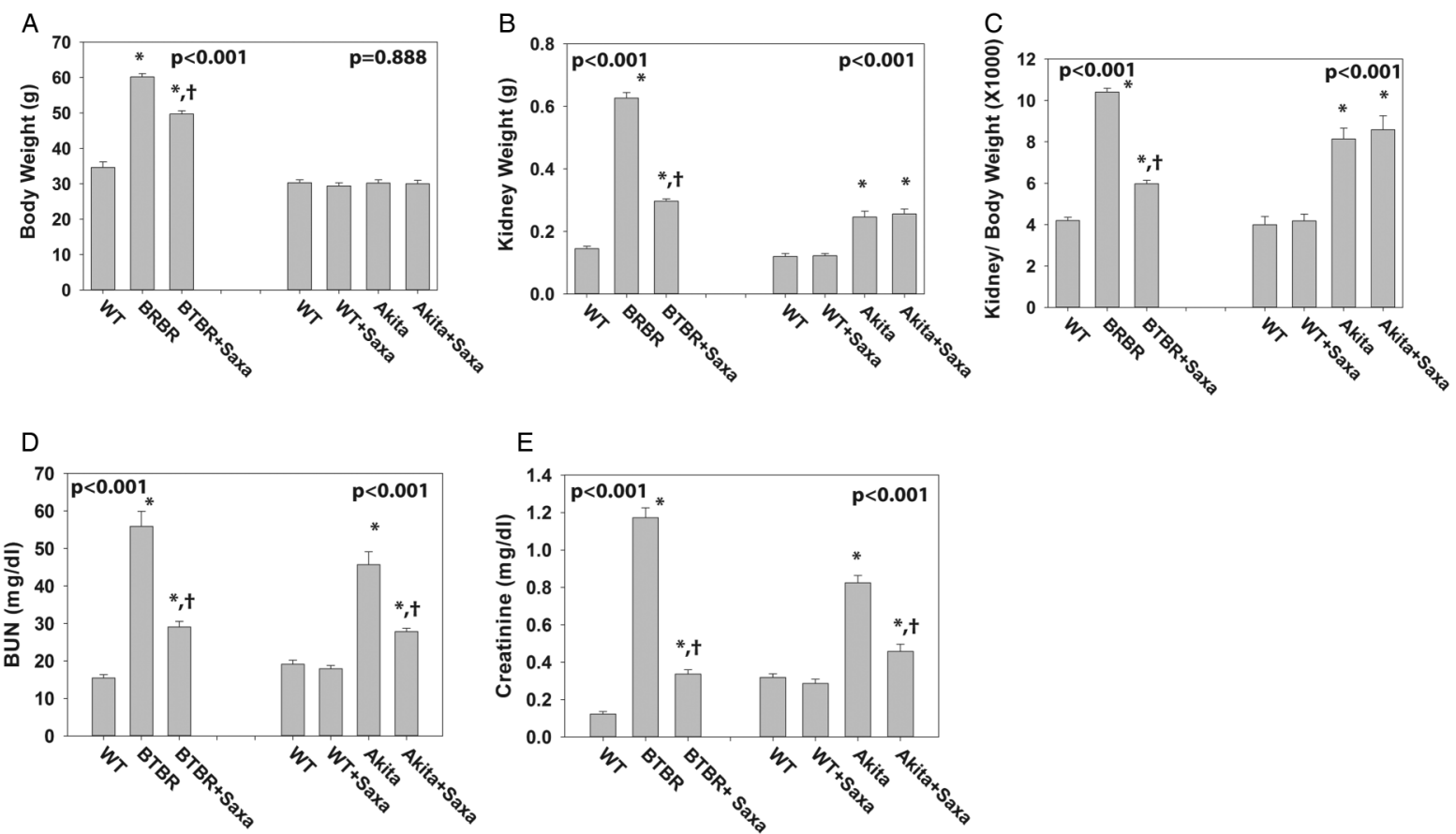

Figure 1 (A) Body weight (g). T2DM: $n=6$ per group. ${ }^{*}<0.001$ vs $W T ; \dagger p<0.001$ vs BTBR. T1DM: $n=5$ per group. (B) Kidney weight (g). T2DM: $n=6$ per group. ${ }^{*} p<0.001$ vs $W T ; \dagger p<0.001$ vs BTBR. T1DM: $n=5$ per group. ${ }^{*} p<0.001$ vs WT. (C) Kidney/body weight ratio ( $\times 1000)$. T2DM: $n=6$ per group. ${ }^{*} p<0.001$ vs $W T ; t p<0.001$ vs BTBR. T1DM: $n=5$ per group. ${ }^{*} p<0.001$ vs WT. (D) Serum BUN. T2DM: $n=5$ per group. ${ }^{*} p<0.009$ vs $W T ; \dagger p<0.001$ vs BTBR. T1DM: $n=5$ per group. ${ }^{*} p<0.031$ vs $W T ; \dagger p<0.001$ vs Akita. (E) Serum creatinine. T2DM: $n=5$ per group. ${ }^{*} p<0.003$ vs WT; $\dagger p<0.001$ vs BTBR. T1DM: $n=5$ per group. ${ }^{*} p<0.035$ vs WT; $t p<0.001$ vs Akita. T1DM, type 1 diabetes mellitus; T2DM, type 2 diabetes mellitus; WT, wild-type.

mice, Saxa had no significant effect on fasting serum glucose in the WT $(118.0 \pm 3.9 \mathrm{mg} / \mathrm{dL} ; \mathrm{p}=0.999)$ or the Akita $(405.0 \pm 11.8 \mathrm{mg} / \mathrm{dL} ; \mathrm{p}=1.0)$ mice ( $\mathrm{n}=5$ per group).

Glucose levels during all time points after glucose loading were significantly higher in the BTBR mice than in the WT mice (figure 2A). Saxa significantly reduced glucose levels in the BTBR mice.

Glucose levels during all time points after glucose loading were significantly higher in the Akita mice compared to the WT mice $(\mathrm{p}<0.001)$ (figure $2 \mathrm{~B})$. Saxa had no effect on glucose levels in the WT $(\mathrm{p}=0.958)$ and the Akita mice $(\mathrm{p}=0.975)$.

Serum CRP levels significantly increased in the BTBR and Akita mice compared to their matched WT mice (figure 3A). Saxa attenuated the increase in the BTBR mice and completely blocked it in the Akita mice. Saxa had no effect on CRP levels in the WT mice. Serum $\mathrm{TNF} \alpha$ (figure 3B), IL-1 $\beta$ (figure 3C), IL-6 (figure 3D) and IL-18 (figure 3E) were significantly higher in the BTBR and Akita mice compared to the WT non-diabetic mice. Saxa significantly attenuated the levels in the BTBR mice and the Akita mice, whereas Saxa had no effect in the WT mice.

In the kidney, levels of ASC1, NLRP3, TNF $\alpha$ and Caspase-1 were significantly higher in the diabetic mice than in the WT mice (figure 4). Saxa had no effect on the expression of these proteins in the WT mice. In contrast, it attenuated the expression of ASC1, NLRP3 and $\mathrm{TNF} \alpha$ in the BTBR and Akita mice. In addition, Saxa attenuated the increase in Caspase-1 expression in the BTBR mice and completely blocked the increase in the Akita mice.

Similar results were obtained in the adipose tissue (figure 5). T1DM and T2DM increased ASC1, NLRP3, TNF $\alpha$ and Caspase-1 levels. Saxa attenuated the increase in ASC1, NLRP3 and TNF $\alpha$ levels. Saxa attenuated the increase in Caspase-1 in BTBR mice and completely blocked the increase in the Akita mice.

RT-PCR confirmed the results of the immunoblotting and ELISA. T1DM and T2DM increased mRNA levels of ASC, NALP3, TNF $\alpha$, IL-1 $\beta$, IL-6 and IL-18 in the kidney (figure 6). Saxa decreased the levels in the BTBR and Akita mice.

H\&E and PAS reagent staining of the kidneys shows glomerular hypertrophy and mesangial expansion in the BTBR and the Akita mice (figure 7). Glomerular area was $3679 \pm 354 \mu^{2}$ in the WT mice. Glomerular area increased to $9178 \pm 695 \mu^{2}$ in the BTBR mice $(p<0.001$ vs WT). Saxa attenuated the increase in glomerular area in the BTBR mice $\left(5369 \pm 339 \mu^{2} ; \mathrm{p}<0.001\right.$ vs BTBR; $\mathrm{p}=0.067 \mathrm{vs}$ WT). Likewise, glomerular area increased in the Akita mice $\left(9823 \pm 744 \mu^{2} ; \mathrm{p}<0.001\right.$ vs WT). Saxa attenuated the increase in glomerular area in the Akita mice $\left(5095 \pm 321 \mathrm{~mm}^{2} ; \mathrm{p}<0.001\right.$ vs Akita; $\mathrm{p}=0.216$ vs WT). Saxa had no effect on glomerular area in the WT mice (3262 $\pm 304 \mathrm{~mm}^{2} ; \mathrm{p}=0.990$ vs WT). The fractional mesangial area was $5.8 \pm 0.4 \%$ in the WT mice. It increased to $22.5 \pm 1.0 \%$ in the BTBR mice $(p<0.001$ vs WT). Saxa attenuated the 

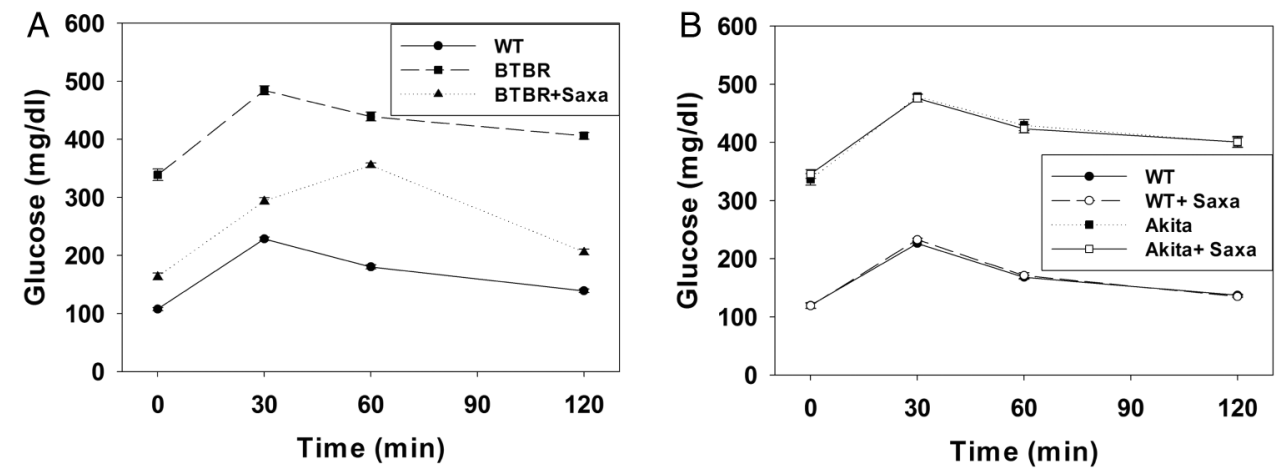

Figure 2 (A) T2DM: serum glucose levels during glucose tolerance test ( $n=6$ per group). Two-way repeat measures ANOVA shows a significant group effect $(p<0.001)$ and time effect $(p<0.001)(p<0.051$ for the groupxtime interaction). (B) T1DM: serum glucose levels during glucose tolerance test ( $n=x$ per group). Two-way repeat measures ANOVA shows a significant group effect $(p<0.001)$ and time effect $(p<0.001)(p<0.001$ for the groupxtime interaction). ANOVA, analysis of variance; T1DM, type 1 diabetes mellitus; T2DM, type 2 diabetes mellitus; WT, wild-type.

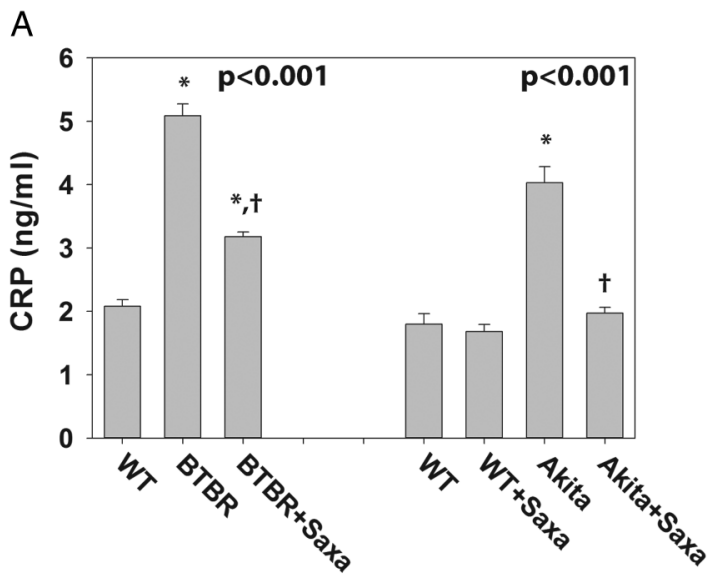

C

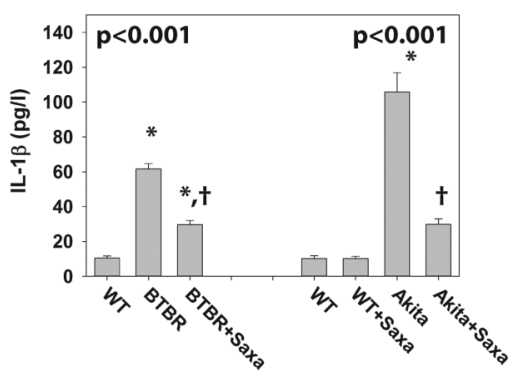

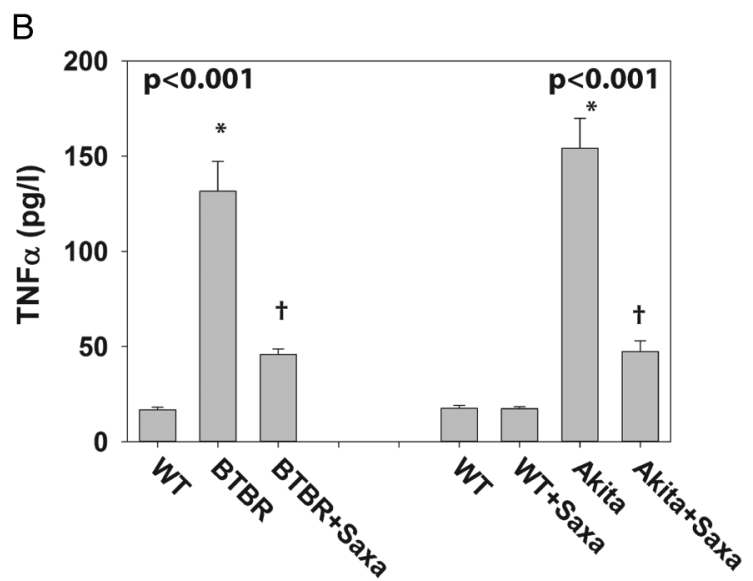

E
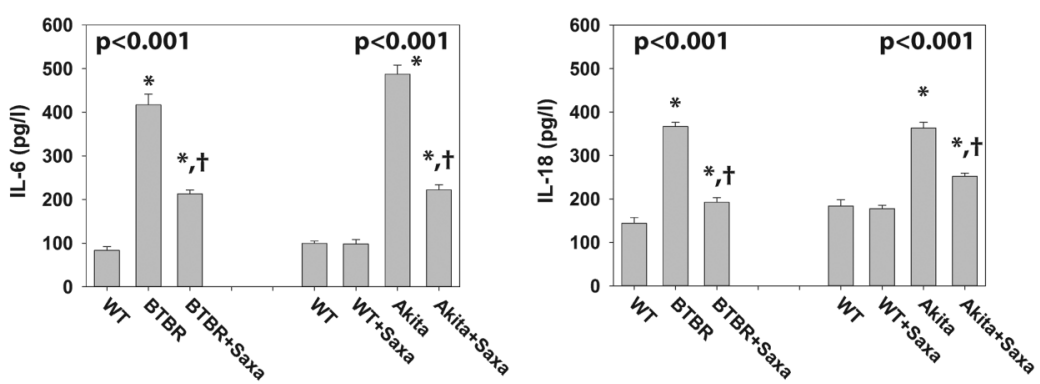

Figure 3 (A) Serum CRP levels. T2DM: $n=6$ per group. * $p<0.001$ vs $W T ; t p<0.001$ vs BTBR. T1DM: $n=5$ per group. * $p<0.001$ vs WT; $\uparrow p<0.001$ vs Akita. (B) Serum TNF $\alpha$. T2DM: $n=6$ per group. ${ }^{*} p<0.001$ vs WT; $\nmid p<0.001$ vs BTBR. T1DM: $n=6$ per group. ${ }^{*} p<0.001$ vs WT; $\dagger p<0.001$ vs Akita. (C) Serum IL-1 $\beta$ T2DM: $n=6$ per group. ${ }^{*} p<0.001$ vs $W T ; ~ † p<0.001$ vs BTBR. T1DM: $n=6$ per group. * $p<0.001$ vs WT; $\dagger p<0.001$ vs Akita. (D) Serum IL-6. T2DM: $n=6$ per group. * $p<0.001$ vs $W T ; \dagger p<0.001$ vs BTBR. T1DM: $n=6$ per group. * $p<0.001$ vs $W T ; \dagger p<0.001$ vs Akita. (E) Serum IL-18. T2DM: $n=6$ per group. ${ }^{*} p<0.03$ vs $W T ; \dagger p<0.001$ vs BTBR. T1DM: $n=6$ per group. ${ }^{*} p<0.003$ vs $W T ; ~ t p<0.001$ vs Akita. CRP, C reactive protein; IL, interleukin; T1DM, type 1 diabetes mellitus; T2DM, type 2 diabetes mellitus; TNF $\alpha$, tumor necrosis factor $\alpha$; WT, wild-type.

increase in the BTBR mice $(11.1 \pm 0.6 \%$; $<<0.001$ vs BTBR; $\mathrm{p}<0.001 \mathrm{vs} \mathrm{WT})$. The fractional mesangial area also increased to $27.3 \pm 1.7 \%$ in the Akita mice $(\mathrm{p}<0.001$ vs WT). Saxa attenuated the increase in the Akita mice $(12.9 \pm 1.0 \%$; $\mathrm{p}<0.001$ vs Akita; $\mathrm{p}=0.001$ vs $\mathrm{WT})$, whereas it had no effect in the WT mice $(5.1 \pm 0.4 \%$; $\mathrm{p}=0.998$ vs WT). Thus, Saxa attenuated the increase in glomerular size and mesangial expansion in the BTBR and Akita mice, without a notable effect in the WT mice.

\section{DISCUSSION}

In the current study, we found that 8-week Saxa treatment significantly attenuated DM-induced activation of 
Figure 4 Immunoblotting

samples ( $A$ and $F$ ) and

densitometric analysis of ASC1

(B and $\mathrm{G}$ ), NLRP3 ( $\mathrm{C}$ and $\mathrm{H}$ ),

TNF $\alpha$ (D and I) and Caspase-1

( $E$ and $J$ ) expression in the

kidney of the WT, BTBR and

Akita mice without and with Saxa

treatment. $\mathrm{N}=4$ per group.

${ }^{*} p<0.02$ vs WT; $t p<0.03$ vs

BTBR or Akita mice. ASC1, apoptosis-associated speck-like protein 1 ; TNF $\alpha$, tumor necrosis factor $\alpha$; WT, wild-type.
A

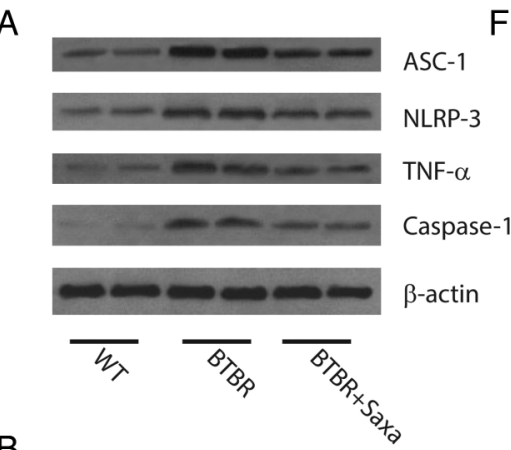

B

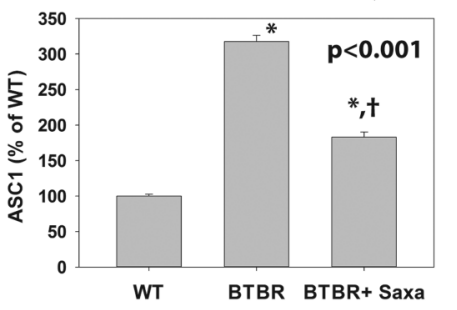

C
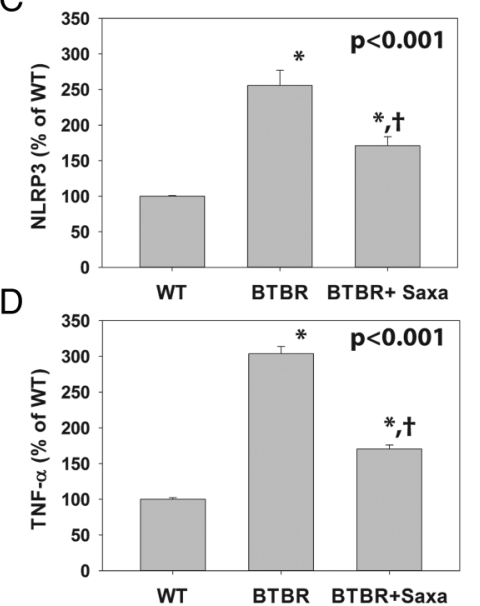

E

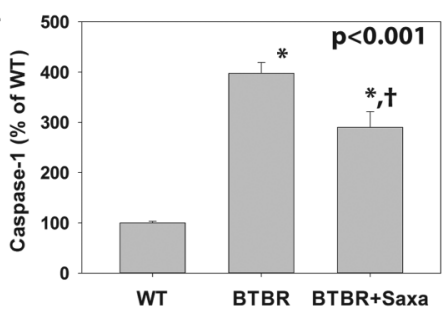

$\mathrm{F}$

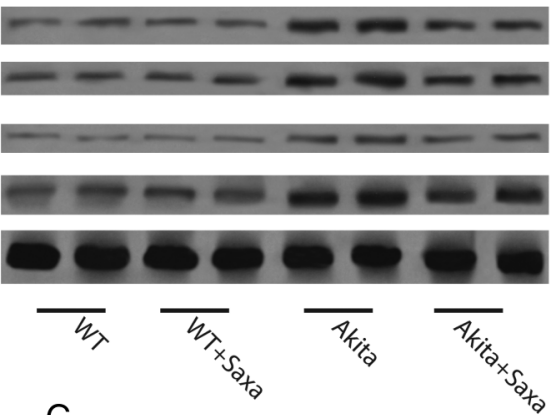

G

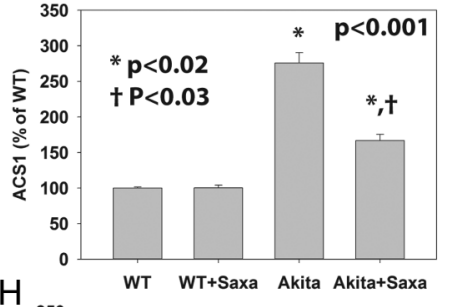

$\mathrm{H}$
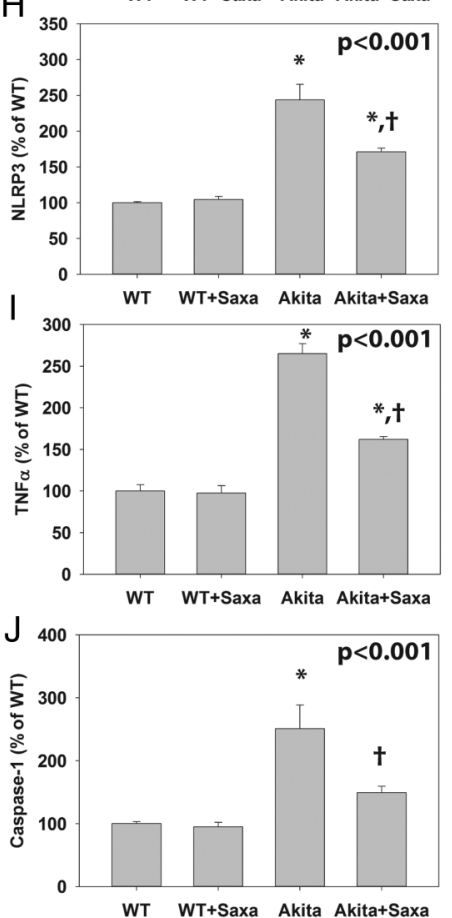

the NLRP3 inflammasome (figures 4 and 5), and significantly reduced the serum levels of CRP, TNF $\alpha$, IL-1 $\beta$, IL-18 and IL-6 (figure 3). Furthermore, Saxa delayed the progression of DN in mice with T2DM, as well as T1DM. Saxa attenuated DM-induced increase in absolute kidney weight and kidney/body weight ratio in the BTBR mice (figure 1), the increase in serum BUN and creatinine in the BTBR and Akita mice (figure 2) and the morphologic changes associated with DN (glomerular hypertrophy and mesangial expansion) in the BTBR and the Akita mice (figure 7).

As expected, Saxa decreased fasting serum glucose levels and improved glucose tolerance after glucose loading in the BTBR mice (a T2DM model), but not in the Akita mice (T1DM model) (figure 2). Thus, the beneficial effects of Saxa on the inflammasome and DN were (at least partial) independent of improvements in glucose tolerance given that Saxa had similar beneficial effects in BTBR and Akita mice, except on the kidney weight and the kidney/body weight ratio.

Several previous studies have suggested that GLP-1 receptor agonists ameliorate $\mathrm{DN}$ in rodents with $\mathrm{T}_{2} \mathrm{DM}^{13}$ as well as with T1DM. ${ }^{11} 14{ }^{17}$ Park et $a l^{13}$ reported that 8-week treatment with exendin-4, a GLP-1 receptor agonist, delayed the progression of $\mathrm{DN}$ in $\mathrm{db} / \mathrm{db}$ mice. They suggested that the beneficial effects are related to improvement in the metabolic anomalies due to better glycemic control and due to increased GLP-1 receptor expression in the kidney. ${ }^{13}$ On the other hand, Hendarto et $a l^{14}$ 
Figure 5 Immunoblotting samples ( $A$ and $F$ ) and densitometric analysis of ASC1 (B and $\mathrm{G}$ ), NLRP3 ( $\mathrm{C}$ and $\mathrm{H}$ ), TNF $\alpha$ (D and I) and Caspase-1 ( $E$ and $J$ ) expression in the adipose tissue of the WT, BTBR and Akita mice without and with Saxa treatment. $\mathrm{N}=4$ per group. ${ }^{*} \mathrm{p}<0.002$ vs $\mathrm{WT} ; \mathrm{\dagger} \mathrm{p}<0.025$ vs BTBR or Akita mice, respectively. ASC1, apoptosis-associated speck-like protein 1; TNF $\alpha$, tumor necrosis factor $\alpha$; WT, wild-type.
A
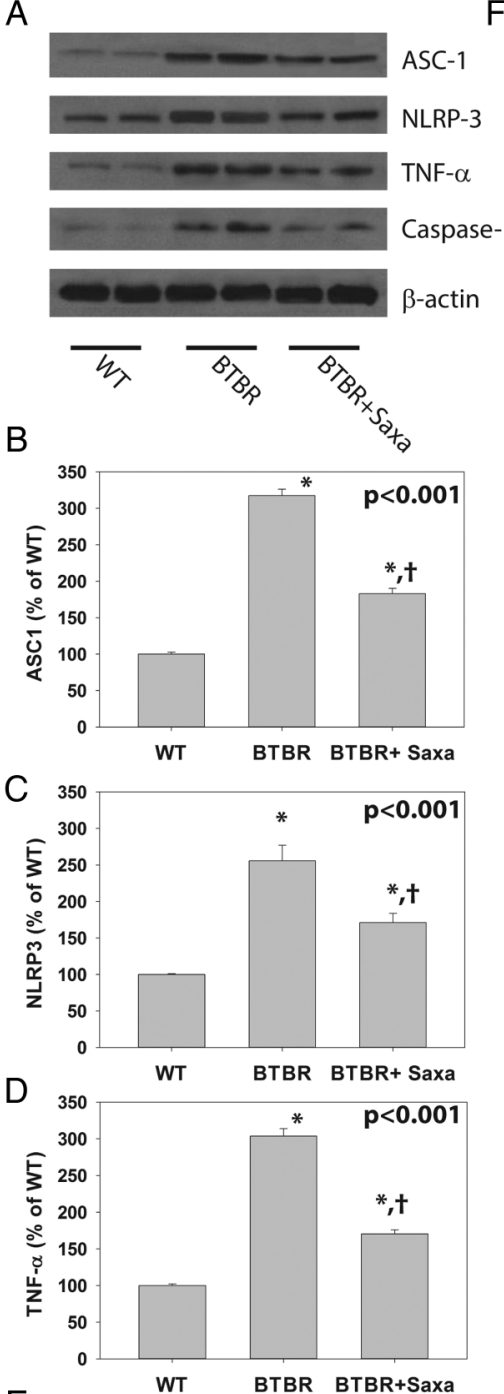

$E$

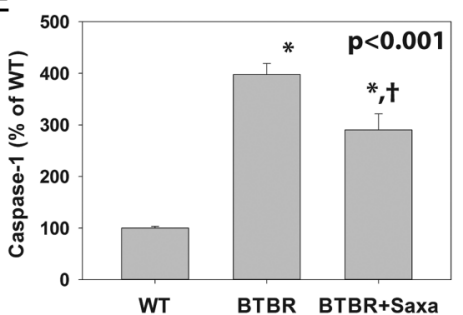

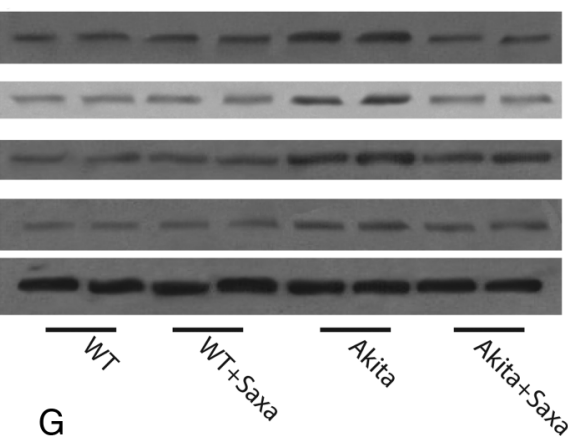

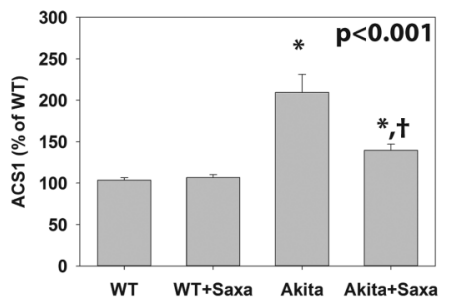

$\mathrm{H}$

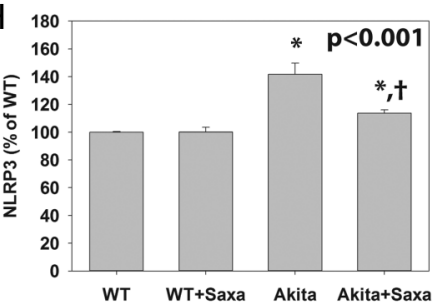

I
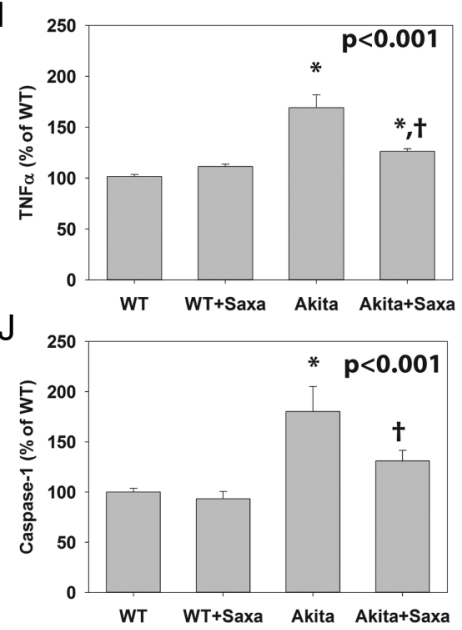

reported that in streptozotocin-induced T1DM rats, liraglutide (a GLP-1 receptor agonist) reduced oxidative stress via a cAMP/protein kinase A-mediated inhibition of renal $\mathrm{NAD}(\mathrm{P}) \mathrm{H}$ oxidases, transforming growth factor- $\beta$ (TGF- $\beta$ ) and fibronectin. The protective effects were blocked by H89, a protein kinase A inhibitor, and SQ22536, an adenylate cyclase inhibitor. Kodera $e t a l^{11}$ reported that 8-week exendin- 4 reduced macrophage infiltration and decreased ICAM-1, TGF- $\beta$ and type IV collagen levels in the kidney of rats with streptozotocin-induced T1DM, without affecting glycemic control. On the other hand, Ojima et al found that 2-week treatment with exendin-1 suppressed protein arginine methyltransfetase-1 (PRMT-1, an enzyme that mainly generates asymmetric dimethylarginine) levels in the kidney of streptozotocin-induced T1DM rats. In addition, exendin-1 decreased the production of advanced glycation end products (AGEs) and their receptor (RAGE), decreased ICAM-1 and monocyte chemoattractant protein 1 (MCP-1) levels and attenuated reactive oxygen species generation without affecting glycemic control. ${ }^{17} \mathrm{An}$ in vitro study confirmed that GLP-1 inhibits RAGE gene expression and reactive oxygen species generation and MCP-1 levels in human cultured renal mesangial cells. ${ }^{16}$ Moreover, using a similar in vitro model, it was shown that GLP-1 receptor activation blocked the angiotensin-II-induced mesangial cell injury. The effect was dependent on protein kinase A activation with downstream inhibition of reactive oxygen species generation, NFKB, ICAM-1 and PAI-1 
Figure 6 mRNA levels of ASC, NALP3, TNF $\alpha$, IL-1 $\beta$, IL-6 and IL-18 in the kidney of WT (control) versus BTBR mice (left column) or WT (control) versus Akita mice (right column). $\mathrm{N}=4$ per group. BTBR: * $p<0.025$ vs control; $\uparrow p<0.045$ vs BTBR. Akita: Akita. ASC, apoptosis-associated speck-like protein; IL, interleukin; TNF $\alpha$, tumor necrosis factor $\alpha$; WT, wild-type. ${ }^{*} \mathrm{p}<0.009$ vs control; $\uparrow \mathrm{p}<0.005$ vs
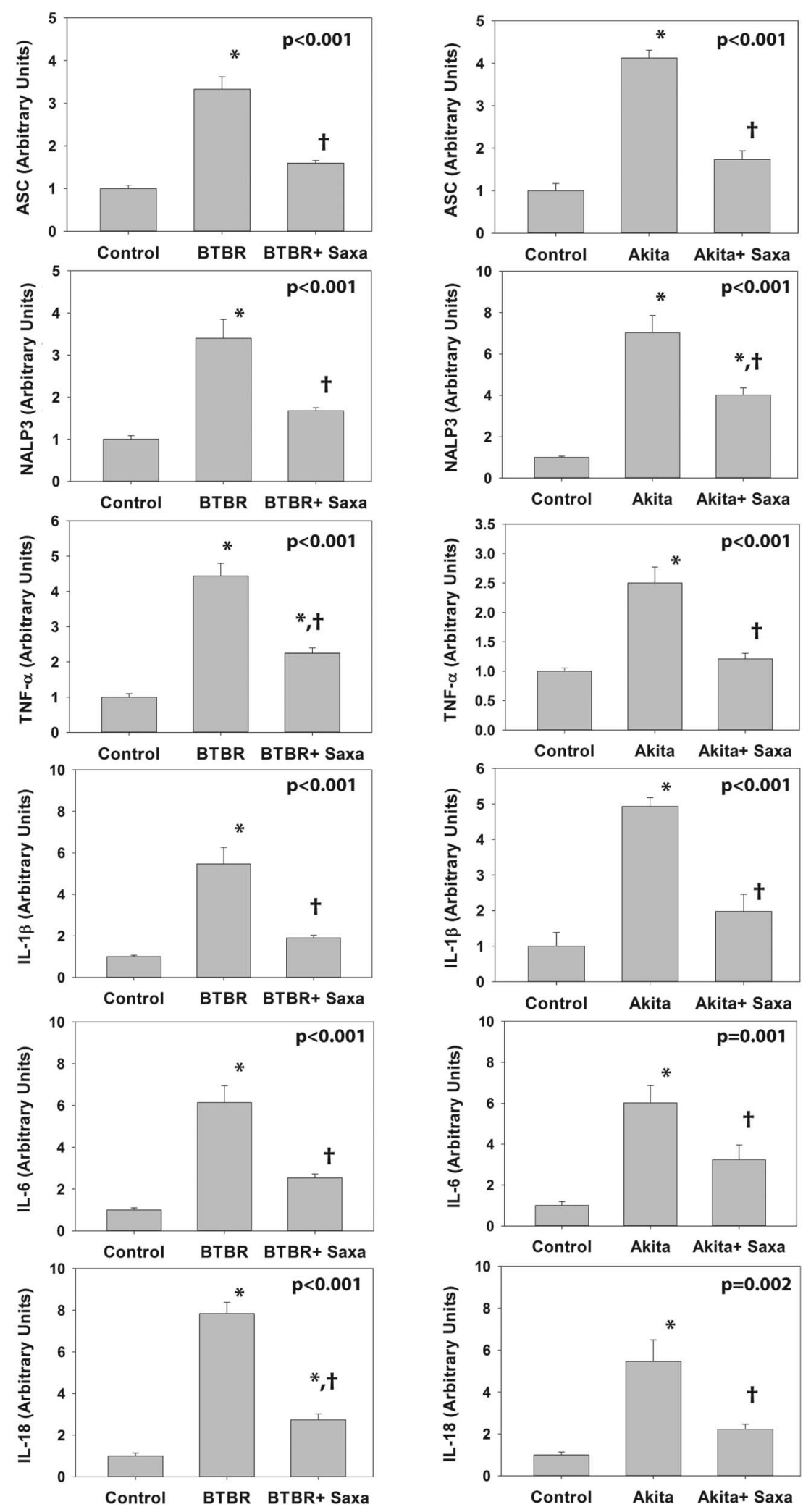

upregulation. ${ }^{15}$ Thus, collectively, the previous studies have suggested a cAMP/protein kinase A-mediated reduction in reactive oxygen species generation and inflammation. It was reported that glyburide prevents Nlrp3 inflammasome activation in vitro; ${ }^{28}$ however, the effects of GLP-1 receptor activation on the Nlrp3 inflammasome has not been reported before. The inflammasome plays an important role in the inflammation associated with $\mathrm{T}_{2} \mathrm{DM}^{21-24}$ and various forms of renal injury. $^{25-27}$ 


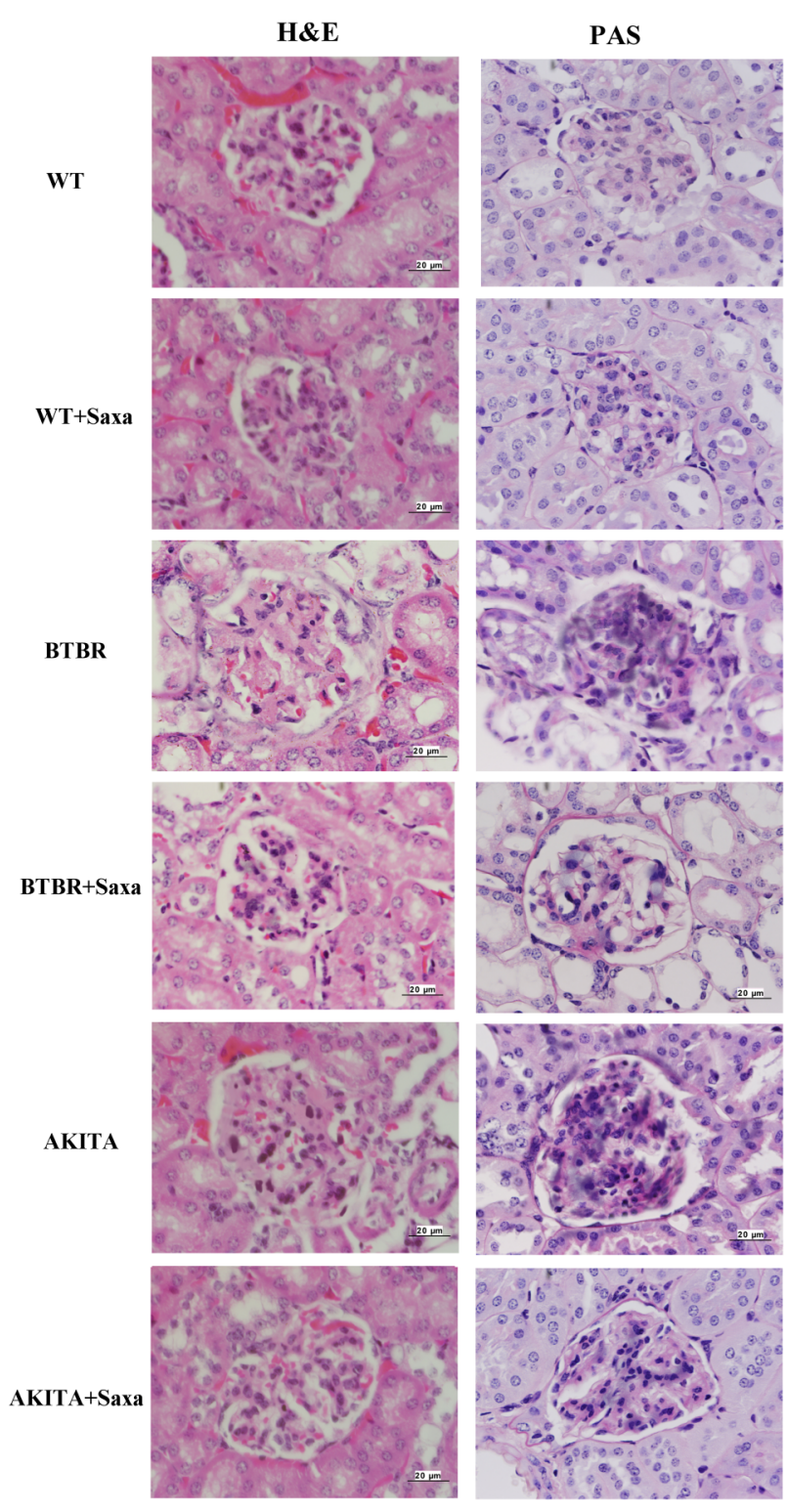

Figure 7 Representative pictures of H\&E and PAS reagent staining of the kidney (original magnification $\times 400$ ). PAS, periodic acid of Schiff; WT, wild-type.

There are scant data on the effects of DPP4Is on the progression of $\mathrm{DN}$ in T2DM and no data on the activation of the Nlrp3 inflammasome. In addition to preventing the degradation of endogenous GLP-1, DPP4Is prevent the degradation of numerous substrates such as GIP, B type natriuretic peptide, substance $\mathrm{P}$, neuropeptide $\mathrm{Y}$, peptide YY, bradykinin and SDF- $1 \alpha$ and, thus, could have effects that differ from that of pure GLP-1 receptor activation. ${ }^{18}$ Kanasaki et al found that linagliptin ameliorated kidney fibrosis in streptozotocin-induced diabetic mice. They observed that levels of microRNA 29s were reduced in the kidneys of the diabetic mice and that linagliptin restored their levels; however, the exact signaling pathway for restoring microRNA 29 levels was not specified. ${ }^{36}$ Kodera et $a l^{20}$ reported that 8-week DPP4I with PKF275-055 attenuated inflammation, NFkB activation and delayed the progression of $\mathrm{DN}$ in rats with streptozotocin-induced T1DM. Nakashima $e t a \rho^{37}$ found that linagliptin ameliorated renal damage in rats with streptozotocin-induced T1DM. Linagliptin did not affect glycemic control, but significantly reduced AGEs RAGE. ${ }^{37}$ Matsui $e t a l^{38}$ reported that the development of DN was delayed in DPP-4-deficient rats than in WT rats with streptozotocin-induced T1DM. As there were no differences in glucose levels and lipid parameters between the WT and the DPP4-deficient mice, they concluded that the protective effect was independent of glycemic control. They suggested that the protective effect was due to blocking of AGEs and RAGE. ${ }^{38}$ In contrast, Rieg et $a l^{19}$ found that in $\mathrm{db} / \mathrm{db}$ mice with T2DM, alogliptin (a DPP4I), in contrast to Exendin-4, failed to inhibit renal fluid and sodium reabsorption. Although an in vitro study suggested that DPP4I represses the Nlrp3 inflammasome and IL-1 $\beta$ expression in macrophages,${ }^{31}$ our study is the first to show that the DPP4I Saxa attenuated Nlrp3 inflammasome activation in vivo in mice with T2DM, as well as T1DM, suggesting that at least part of the beneficial effect is independent of improvements in glucose tolerance.

The Nlrp3 inflammasome complex activates caspase-1 that regulates the activation and secretion of IL-1 $\beta$ and IL-18 from cells. ${ }^{21} 232526$ The inflammatory cytokines TNF $\alpha$, IL-1 $\beta$, IL- 6 and IL-18 have crucial roles in mediating the glomerular and tubulointerstitial injury induced by diabetes. ${ }^{39}{ }^{40}$ Here we are showing that in addition to reducing the levels of the components of the Nlrp3 inflammasome, Saxa attenuated the increase in all these four cytokines in T2DM and T1DM models.

The exact mechanism(s) of attenuating the DM-induced activation of the Nlrp3 inflammasome by Saxa have not been elucidated. Previous studies suggested that the anti-inflammatory effects of GLP-1 receptor activation are dependent on cAMP-induced protein kinase A activation. ${ }^{14}{ }^{15}$ Our group has previously shown that GLP-1 receptor agonists and DPP4Is increased the production of 15-epi-lipoxin $\mathrm{A}_{4}$, an arachidonic acid mediator with potent anti-inflammatory and inflammation resolution properties via activation of protein kinase $\mathrm{A}$ and 5-lipoxygenase. ${ }^{41}{ }^{42}$ 15-Epi-lipoxin $\mathrm{A}_{4}$ suppressed activation of the inflammasome. ${ }^{43} 44$ Thus, inhibition of the inflammasome in our models might be explained by 15-epi-lipoxin $\mathrm{A}_{4}$. However, protein kinase $\mathrm{A}$ has numerous other targets. Further studies are needed to establish the role of 15-epi-lipoxin $\mathrm{A}_{4}$ in mediating the protective effect of DPP4Is. It has been suggested that protein kinase A inactivates phospho-c-Raf/phosphor-Erk 1/2, which are activated by angiotensin II. ${ }^{12}$ This attenuates angiotensin II-induced upregulation of PAI-1, CD68 and CXCL2 levels. ${ }^{12}$

A recent study suggested that in streptozotocininduced type 1 diabetic mice, the levels of endothelial DPP4, integrin $\beta 1$ and phosphor-integrin $\beta 1$ were all higher than in non-diabetic mice. ${ }^{45}$ The DPP4I linagliptin suppressed endothelial levels of DPP4, integrin $\beta 1$ and phospho-integrin $\beta 1$, reduced plasma cystatin $\mathrm{C}$ 
levels and reduced kidney fibrosis. Suppression of DPP4 by siRNA was associated with suppression of integrin $\beta 1$ and vice versa. Knockdown of either integrin $\beta 1$ or DPP4 resulted in the silencing of TGF- $\beta 2$-induced TGF- $\beta$ receptor heterodimer formation, smad3 phosphorylation and endothelial-to-mesenchymal transition. ${ }^{45}$ The authors suggested that inhibiting DPP4 may be a therapeutic target for treating kidney fibrosis in diabetes. ${ }^{45} \mathrm{It}$ is yet unclear whether such an interaction between integrin $\beta 1$ and DPP4 affects inflammasome activation in mediating fibrosis. ${ }^{45}$

\section{Limitations}

Although it is well established that DPP4Is increase the levels of GLP-1, in the current study, we did not measure tissue and serum levels of GLP-1. We have not collected urine sample to study the effect of treatment on microalbuminuria.

In conclusion, we found that Saxa attenuated the diabetes-induced activation of the Nlrp3 inflammasome and the upregulation of the proinflammatory cytokines TNF $\alpha$, IL-1 $\beta$, IL- 6 and IL-18 in mice with T2DM and T1DM. Saxa significantly delayed the progression of DN in the two models. The fact that effects of Saxa were comparable in the Akita and BTBR mice, despite the fact that Saxa had no effects on glycemic control in the T1DM model, suggests a signaling pathway that is (at least partially) independent of glucose-lowering effect of SAXA. Our important findings in rodent models should be confirmed in patients with T1DM and T2DM, as inhibition of the Nlrp3 inflammasome and reducing TNF $\alpha$, IL-1 $\beta$, IL-6 and IL-18 levels might have significant implications in the clinical setting for preventing DN.

\section{Author affiliations}

${ }^{1}$ Department of Biochemistry and Molecular Biology, University of Texas Medical Branch, Galveston, Texas, USA

${ }^{2}$ Section of Cardiology, Department of Medicine, Baylor College of Medicine, Houston, Texas, USA

${ }^{3}$ Section of Endocrinology, Department of Medicine, Baylor College of Medicine, Houston, Texas, USA

${ }^{4}$ Department of Anesthesiology, First Affiliated Hospital of Kunming Medical University, Kunming, Yunnan, China

Contributors YB contributed to study design, data collection and analysis, statistical analysis and writing the manuscript. MB involved in data analysis, statistical analysis and cowriting the manuscript. JQ and MB involved in data analysis, searching literature and editing the manuscript. YY contributed to study design, submitting the grant, conduction of the experiments, data collection and analysis, literature search and editing the manuscript.

Funding This work was supported by a grant from AstraZeneca to YB and YY by a research grant from the American Diabetes Association to MB (07-13-TS-04).

Competing interests YB has received research grants from AstraZeneca and Boehringer Ingelheim. He has received lecture fees from Daiichi Sankyo and AstraZeneca. MB has received research grants from AstraZeneca, Boehringer Ingelheim, Eli-Lilly and Novo Nordisk. He has received lecture fees from Takeda Pharmaceuticals and Sanofi Aventis and is a consultant to Merck and Genentech. YY has received research grants from AstraZeneca and Boehringer Ingelheim.

Provenance and peer review Not commissioned; externally peer reviewed.

Data sharing statement No additional data are available.
Open Access This is an Open Access article distributed in accordance with the Creative Commons Attribution Non Commercial (CC BY-NC 4.0) license, which permits others to distribute, remix, adapt, build upon this work noncommercially, and license their derivative works on different terms, provided the original work is properly cited and the use is non-commercial. See: http:// creativecommons.org/licenses/by-nc/4.0/

\section{REFERENCES}

1. Saran R, Li Y, Robinson B, et al. US Renal Data System 2014 Annual Data Report: epidemiology of kidney disease in the United States. Am J Kidney Dis 2015;66(Suppl 1):Svii, S1-305.

2. Mima A. Diabetic nephropathy: protective factors and a new therapeutic paradigm. J Diabetes Complications 2013;27:526-30.

3. Muskiet MH, Smits MM, Morsink LM, et al. The gut-renal axis: do incretin-based agents confer renoprotection in diabetes? Nat Rev Nephrol 2014;10:88-103.

4. Drucker DJ. The biology of incretin hormones. Cell Metab 2006;3:153-65.

5. Campos RV, Lee YC, Drucker DJ. Divergent tissue-specific and developmental expression of receptors for glucagon and glucagon-like peptide-1 in the mouse. Endocrinology 1994;134:2156-64.

6. Körner M, Stöckli M, Waser B, et al. GLP-1 receptor expression in human tumors and human normal tissues: potential for in vivo targeting. J Nucl Med 2007;48:736-43.

7. Schlatter P, Beglinger C, Drewe J, et al. Glucagon-like peptide 1 receptor expression in primary porcine proximal tubular cells. Regul Pept 2007;141:120-8.

8. Crajoinas RO, Oricchio FT, Pessoa TD, et al. Mechanisms mediating the diuretic and natriuretic actions of the incretin hormone glucagon-like peptide-1. Am J Physiol Renal Physiol 2011;301: F355-63.

9. Pezeshki A, Muench GP, Chelikani PK. Short communication: expression of peptide $Y Y$, proglucagon, neuropeptide $Y$ receptor $Y 2$, and glucagon-like peptide-1 receptor in bovine peripheral tissues. J Dairy Sci 2012;95:5089-94.

10. Liu H, Dear AE, Knudsen LB, et al. A long-acting glucagon-like peptide-1 analogue attenuates induction of plasminogen activator inhibitor type-1 and vascular adhesion molecules. $J$ Endocrinol 2009;201:59-66.

11. Kodera R, Shikata K, Kataoka HU, et al. Glucagon-like peptide-1 receptor agonist ameliorates renal injury through its anti-inflammatory action without lowering blood glucose level in a rat model of type 1 diabetes. Diabetologia 2011;54:965-78.

12. Mima A, Hiraoka-Yamomoto J, Li Q, et al. Protective effects of GLP-1 on glomerular endothelium and its inhibition by PKC $\beta$ activation in diabetes. Diabetes 2012;61:2967-79.

13. Park CW, Kim HW, Ko SH, et al. Long-term treatment of glucagon-like peptide-1 analog exendin-4 ameliorates diabetic nephropathy through improving metabolic anomalies in $\mathrm{db} / \mathrm{db}$ mice. $J$ Am Soc Nephrol 2007;18:1227-38.

14. Hendarto $H$, Inoguchi $T$, Maeda $Y$, et al. GLP-1 analog liraglutide protects against oxidative stress and albuminuria in streptozotocin-induced diabetic rats via protein kinase A-mediated inhibition of renal $\mathrm{NAD}(\mathrm{P}) \mathrm{H}$ oxidases. Metab Clin Exp 2012;61:1422-34.

15. Ishibashi Y, Matsui T, Ojima A, et al. Glucagon-like peptide-1 inhibits angiotensin II-induced mesangial cell damage via protein kinase $A$. Microvasc Res 2012;84:395-8.

16. Ishibashi $Y$, Nishino $Y$, Matsui $T$, et al. Glucagon-like peptide-1 suppresses advanced glycation end product-induced monocyte chemoattractant protein-1 expression in mesangial cells by reducing advanced glycation end product receptor level. Metab Clin Exp 2011;60:1271-7.

17. Ojima A, Ishibashi $Y$, Matsui $T$, et al. Glucagon-like peptide-1 receptor agonist inhibits asymmetric dimethylarginine generation in the kidney of streptozotocin-induced diabetic rats by blocking advanced glycation end product-induced protein arginine methyltranferase-1 expression. Am J Pathol 2013;182:132-41.

18. Yoon $A H, Y e$ Y, Birnbaum Y. Dipeptidyl peptidase IV inhibitors and ischemic myocardial injury. J Cardiovasc Pharmacol Ther 2014;19:417-25.

19. Rieg T, Gerasimova M, Murray F, et al. Natriuretic effect by exendin-4, but not the DPP-4 inhibitor alogliptin, is mediated via the GLP-1 receptor and preserved in obese type 2 diabetic mice. Am J Physiol Renal Physiol 2012;303:F963-71.

20. Kodera R, Shikata K, Takatsuka T, et al. Dipeptidyl peptidase-4 inhibitor ameliorates early renal injury through its anti-inflammatory action in a rat model of type 1 diabetes. Biochem Biophys Res Commun 2014;443:828-33. 
21. De Nardo D, Latz E. NLRP3 inflammasomes link inflammation and metabolic disease. Trends Immunol 2011;32:373-9.

22. Masters SL, Dunne A, Subramanian SL, et al. Activation of the NLRP3 inflammasome by islet amyloid polypeptide provides a mechanism for enhanced IL-1 $\beta$ in type 2 diabetes. Nat Immunol 2010;11:897-904.

23. Dixit VD. Nlrp3 inflammasome activation in type 2 diabetes: is it clinically relevant? Diabetes 2013;62:22-4.

24. Lee HM, Kim JJ, Kim HJ, et al. Upregulated NLRP3 inflammasome activation in patients with type 2 diabetes. Diabetes 2013;62:194-204.

25. Anders HJ, Lech M. NOD-like and Toll-like receptors or inflammasomes contribute to kidney disease in a canonical and a non-canonical manner. Kidney Int 2013;84:225-8.

26. Anders HJ, Muruve DA. The inflammasomes in kidney disease. J Am Soc Nephrol 2011;22:1007-18.

27. Chen K, Zhang J, Zhang W, et al. ATP-P2X4 signaling mediates NLRP3 inflammasome activation: a novel pathway of diabetic nephropathy. Int J Biochem Cell Biol 2013;45:932-43.

28. Lamkanfi M, Mueller JL, Vitari AC, et al. Glyburide inhibits the Cryopyrin/Nalp3 inflammasome. J Cell Biol 2009;187:61-70.

29. Hu QH, Zhang $X$, Pan $Y$, et al. Allopurinol, quercetin and rutin ameliorate renal NLRP3 inflammasome activation and lipid accumulation in fructose-fed rats. Biochem Pharmacol 2012;84:113-25.

30. Wang C, Pan Y, Zhang QY, et al. Quercetin and allopurinol ameliorate kidney injury in STZ-treated rats with regulation of renal NLRP3 inflammasome activation and lipid accumulation. PLoS One 2012;7:e38285.

31. Dai Y, Dai D, Wang X, et al. DPP-4 inhibitors repress NLRP3 inflammasome and interleukin-1beta via GLP-1 receptor in macrophages through protein kinase $\mathrm{C}$ pathway. Cardiovasc Drugs Ther 2014;28:425-32.

32. Betz B, Conway BR. An update on the use of animal models in diabetic nephropathy research. Curr Diab Rep 2016;16:18.

33. Hudkins KL, Pichaiwong W, Wietecha T, et al. BTBR Ob/Ob mutant mice model progressive diabetic nephropathy. J Am Soc Nephrol 2010;21:1533-42.

34. Rangan GK, Tesch GH. Quantification of renal pathology by image analysis. Nephrology (Carlton) 2007;12:553-8.
35. Solini A, Menini S, Rossi C, et al. The purinergic $2 X 7$ receptor participates in renal inflammation and injury induced by high-fat diet: possible role of NLRP3 inflammasome activation. $J$ Pathol 2013;231:342-53.

36. Kanasaki K, Shi S, Kanasaki M, et al. Linagliptin-mediated DPP-4 inhibition ameliorates kidney fibrosis in streptozotocin-induced diabetic mice by inhibiting endothelial-to-mesenchymal transition in a therapeutic regimen. Diabetes 2014;63:2120-31.

37. Nakashima S, Matsui T, Takeuchi M, et al. Linagliptin blocks renal damage in type 1 diabetic rats by suppressing advanced glycation end products-receptor axis. Horm Metab Res 2014;46:717-21.

38. Matsui T, Nakashima S, Nishino Y, et al. Dipeptidyl peptidase-4 deficiency protects against experimental diabetic nephropathy partly by blocking the advanced glycation end products-receptor axis. Lab Invest 2015;95:525-33.

39. Awad AS, You H, Gao T, et al. Macrophage-derived tumor necrosis factor-alpha mediates diabetic renal injury. Kidney Int 2015;88:722-33.

40. Sun L, Kanwar YS. Relevance of TNF- $\alpha$ in the context of other inflammatory cytokines in the progression of diabetic nephropathy. Kidney Int 2015;88:662-5.

41. Birnbaum Y, Castillo AC, Qian J, et al. Phosphodiesterase III inhibition increases cAMP levels and augments the infarct size limiting effect of a DPP-4 inhibitor in mice with type-2 diabetes mellitus. Cardiovasc Drugs Ther 2012;26:445-56.

42. Ye Y, Qian J, Castillo AC, et al. Phosphodiesterase-3 inhibition augments the myocardial infarct size-limiting effects of exenatide in mice with type 2 diabetes. Am J Physiol Heart Circ Physiol 2013;304:H131-41.

43. Li Q, Tian Y, Wang ZF, et al. Involvement of the spinal NALP1 inflammasome in neuropathic pain and aspirin-triggered-15-epi-lipoxin A4 induced analgesia. Neuroscience 2013;254:230-40.

44. Tian Y, Liu M, Mao-Ying QL, et al. Early single Aspirin-triggered Lipoxin blocked morphine anti-nociception tolerance through inhibiting NALP1 inflammasome: involvement of PI3K/Akt signaling pathway. Brain Behav Immun 2015;50:63-77.

45. Shi S, Srivastava SP, Kanasaki M, et al. Interactions of DPP-4 and integrin $\beta 1$ influences endothelial-to-mesenchymal transition. Kidney Int 2015;88:479-89. 